\title{
THE STATE OF RESEARCH EQUIPMENT IN SOUTH AFRICA: TOWARDS BEST PRACTICE
}

\author{
M. Piperakis ${ }^{1}$ and A. Pouris ${ }^{2}$ \\ Institute for Technological Innovation, \\ University of Pretoria, South Africa \\ 1mpiperakis@manotec.com, ${ }^{2}$ anastassios.pouris@up.ac.za
}

\begin{abstract}
The article makes the point that instrumentation is critical to the science and technology infrastructure. Furthermore, it reports the results of a relevant national survey. Information is available for three groups - (i) research councils, (ii) universities, and (iii) technikons, museums and government departments as one group. This level of aggregation has been chosen in order to assist in the development of recommendations related to national policy. In addition, the state of equipment in the country is compared and contrasted with those in a number of countries abroad. Although it emerges that the Research Councils in South Africa possess the largest quantity of equipment, for the purpose of this paper, focus is given to the results of the Universities group since it is felt this provides greater ease of comparison to other developing countries.
\end{abstract}

\section{OPSOMMING}

Die artikel beklemtoon dat instrumentasie krities is tot die wetenskap- en tegnologieinfrastruktuur. Verder rapporteer dit resultate van 'n toepaslike nasionale ondersoek. Informasie word verskaf volgens drie kategorië, naamlik - (i) Navorsingsrade, (ii) Universiteite en (iii) Universiteite van Tegnologie (Tegnikons), asook Museums en Staatsdepartemente. Hierdie samestelling is gekies om te help met die ontwikkeling van voorstelle t.o.v. ' $n$ nasionale riglyn. Die toestand van toerusting in die land word vergelyk met dié van verskeie internasionale lande. Alhoewel dit blyk dat die Navorsingsrade in Suid-Afrika die grootste hoeveelheid toerusting besit, vir die doel van hierdie dokument, is daar klem gelê op die Universiteitsgroep, omdat dit beskou word as meer vergelykbaar met die situasie in ander ontwikkelende lande.

\footnotetext{
${ }^{1}$ This author was enrolled for a $\mathrm{PhD}$ at the Institute of Technological Innovation, University of Pretoria
} 


\section{INTRODUCTION}

This investigation, aiming to acquire, organise and analyse data related to training and research equipment in the country, has two aspects: firstly to collect the necessary data, digitise and make it available in a database and secondly, to shed light on policy and management issues related to research and training (R\&T) equipment at a national level in the country.

Scientific instrumentation derives its importance from its contribution to research, economic growth and human resource development [1]. Scientific instruments are the tools used to discover new knowledge. Throughout the history of science revolutionary ideas would have faded and disappeared if they have not been supported by appropriate instrumentation. Without the telescope, Galileo could only guess the nature of the solar system. Without the microscope, van Leeuwenhoek could only speculate on the nature of microbial life.

The role of instrumentation in research is pervasive. A study conducted for the NSF, by Computer Horizon Inc. Research (CHI), entitled Analysis of the Contribution of Scientific Instrumentation to Highly Cited Research [1], investigated the role of instrumentation by examining highly cited research papers. The study found that "the fields of botany and organic chemistry were highly instrumentation dependent with nearly 100 percent of the papers describing research in which instrumentation played a necessary role”.

The findings of a survey of 4,000 British innovations by Pavitt [2] show that advances in instrumentation have played an increasingly central role in innovation by firms principally in the chemicals, metals, mechanical engineering and electrical/electronic industries. Moreover, figures on patents granted in the US indicate that 'professional and scientific instruments' have accounted for a growing proportion of the overall total, rising from 11\% in 1978 to 13.6\% in 1988, (National Science Board [3]).

In the fields of solid state physics and electrical engineering the findings pointed to "more diversity in the role of instrumentation and in the actual instruments mentioned. In solid state physics, the reported research depended directly on necessary instrumentation in 55\% of the papers".

The pervasive dependence on instrumentation across a great many scientific fields is exemplified in the study's findings that only nine percent of papers across the five fields examined were judged to require no instrumentation - with a computer not being counted as instrumentation in some papers. This strongly indicates a critical importance and dependence on instrumentation in the scientific process.

The importance of instrumentation for the advancement of science is also highlighted by the number of Nobel prizes awarded for the development of novel instruments and new experimental techniques like the aperture synthesis radio-telescope, phasecontrast microscopy and nuclear magnetic resonance. 
Between 1901 and 1990, 15 Nobel Prizes were awarded for the development of new instruments and another eight were awarded for new experimental techniques. That is, more than a quarter of the awards were instrument related.

Instrumentation moreover is not restricted to disciplines traditionally dependent on expensive instrumentation - big science and small instrument-intensive fields like analytical chemistry and engineering. Disciplines with historically low instrumentation needs (e.g. archaeology and cognitive psychology) become more and more dependent on instrumentation. Bio-molecular archaeology, dendrochronology research and resistivity surveying are some of the newly emerging disciplines/techniques with high instrumentation needs within archaeology; while "player based simulations" provide new insights into economics, sociology, marketing and other social science disciplines.

As far as human resources development is concerned, scientific instrumentation is a key parameter (National Audit Office, [4]). The National Science Foundation (NSF) states that, "Science and engineering education involves hands-on experience at all levels. Developing the human potential in all segments of our society means nurturing curiosity and developing skills for inquiry. From grade school to graduate school, interest is awakened and learning is enhanced through experience with real instruments. Each participant in a learning community, benefits from sharing experiences and data over computer networks such as the National Information Infrastructure - the 'information superhighway'.” [5].

\section{METHODOLOGY}

The objective of the "Survey of Research and Training Equipment in South Africa" is to create a related database and analyse the collected information in order to cast light upon the current state, stock and needs for equipment and associated policy and management issues.

The sectors invited to take part in the Survey are those in higher education (universities and technikons), science councils and government research establishments. The criterion for inclusion was the availability of a piece of equipment used wholly or partially for research and/or training. All eligible equipment located in the institutions concerned was in scope. A set of equipment items connected together and used as a working whole was recommended to be included as a single piece of equipment. Free-standing computers were excluded, although computers dedicated to other instruments were included.

To be included in the Survey, equipment had to have a replacement value of above R80 000. This level was selected in order to make the collection of the data costfeasible. It was decided not to impose a ceiling value on the equipment to be included in the study. The higher education institutions, research councils and other government research establishments were approached comprehensively (on a censusapproach). A questionnaire was developed, piloted with a number of institutions, and was distributed to higher education institutions to research councils and government departments. 
The questionnaire was divided into two parts. Part A of the questionnaire was concerned with the adequacy and need for research/training equipment. Participants were asked to complete one questionnaire for each reporting unit (e.g. university departments). Questions were asked concerning the overall capability of the equipment of the department/unit for research and teaching; the availability of resources and expertise related to equipment; the cost and types of equipment required for adequate performance of the department/unit; and possible agreements with manufacturers/suppliers.

Part B of the questionnaire was an inventory of the available items of equipment and respondents were requested to complete one questionnaire for each piece of equipment or a set of items of equipment inter-connected and used as a working whole. The questions asked attempted to provide information concerning the:

- identification and technical capabilities of the equipment;

- various facets of utilisation;

- means and sources of acquisition;

- age and remaining useful life; and

- availability of the equipment to be utilised by external institutions.

The questionnaires were sent to the identified institutions for completion. Each institution was handled on an individual basis. Certain institutions, for example, requested that their heads of departments/units should be approached directly while others requested working through their administration. The University of Stellenbosch (US) sent the data directly from their developed database. Despite the variability on the approaches used for the distribution of the questionnaires, 2700 were distributed centrally by the Survey.

A number of institutions were visited to improve response rates and to gain first hand experience of issues related to research equipment. The broad issues included in the agenda and discussed in the meetings were as follows:

- means of securing maximum response and capturing of meaningful information by the Survey;

- identifying the position of research and training equipment in the hierarchy of strategic needs of the institution;

- optimising the national situation of securing access to research and training equipment including the role of government; and

- other issues.

\section{FINDINGS}

The findings were broken down into a broad picture emerging from the investigation and subsequently outlined the results related to major groups in more detail - i.e. research councils (RCs), universities, and as one group technikons, museums and government departments. 
The investigation identified 2168 equipments with a total replacement value of R1 792 million. The majority of the equipment was found at the RCs which declared that they owned 966 equipments valued at R1 120 million. The universities declared 884 items of equipment with a replacement value of R376 million. The technikons are the third major group owning equipment. They declared that they had 202 items of equipment with a replacement value of R40 million. The museums and government departments declared that they owned 118 equipments with a value of R256 million (Figure 1).

\section{Number of equipment items}

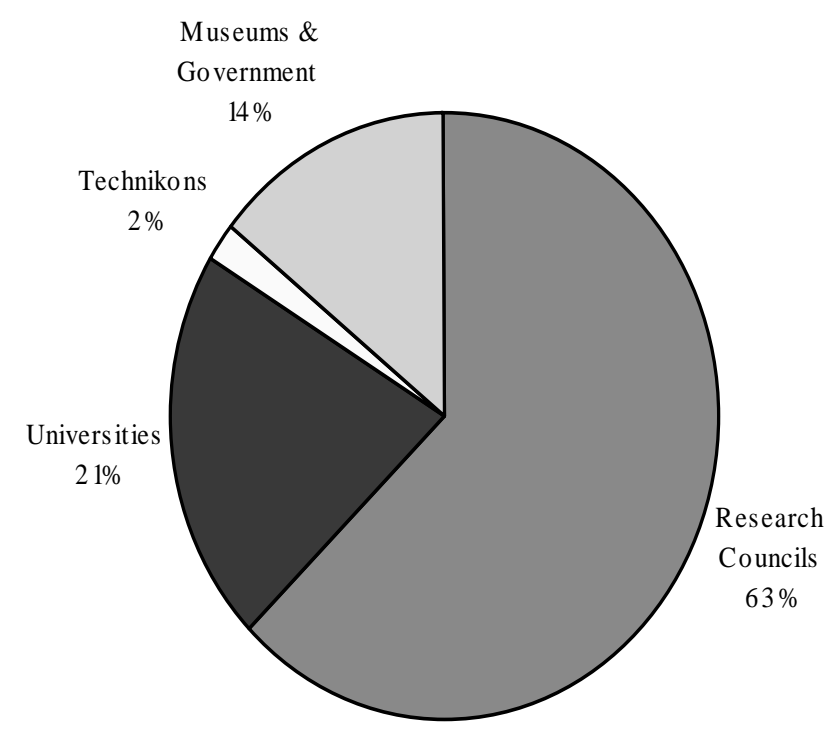

\section{Replacement Value}

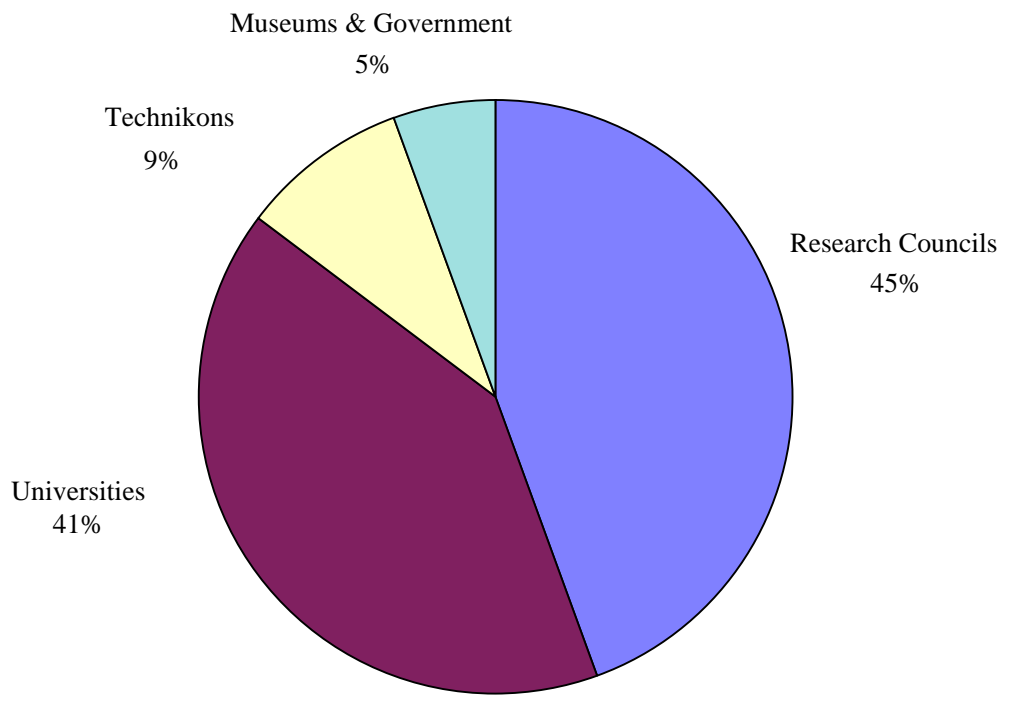

Figure 1: Distribution of R\&T Equipment in South Africa 
The respondents declared the existence of 290 items of equipment with a value of R174 million as being state-of-the-art. That represents only $13.4 \%$, in terms of value, of the total stock of equipment. In comparison, a recent investigation in the United Kingdom (UK) identified that nearly one-fifth of the total stock of instruments is considered to be state-of-the-art. Furthermore, the opinion of the British researchers/academics substantiated by case studies indicated that the UK research groups in leading universities were in most cases more constrained in the field of equipment than their counterparts in the United States (US) and continental Europe. The respondents declared that they need R224 million to acquire sufficient items of equipment so that their units would be able to fulfill their mission. However, the wish-list, even though limited to two items of equipment per responding unit, included equipment valued at R429 million.

The respondents indicated that equipment valued at R512 million had to be replaced within the next five years. This is a substantial amount for the South African circumstances and presents a number of opportunities (e.g. for procurement) and threats for the scientific infrastructure. The largest supplier-countries of equipment in South Africa, in descending order, are the USA, Germany, England and Japan.

The average utilisation time of the current stock of equipment was estimated at 29.68 hours per week. The difference in average utilisation rates between research councils (31.8 h/week) and universities (27.7 h/week) is not significant even though it was expected that the different modus operandi between the two types of institutions would have reflected in the utilisation rates of their equipment.

\section{SURVEY RESULTS FOR SA UNIVERSITIES}

There are 21 universities in South Africa and all were invited to participate in the equipment investigation. Eighteen institutions responded to the invitation and sent lists of equipment in their organisations. This represents an $86 \%$ response.

The majority of the university respondents (64\%) ranked the overall capability of their equipment (in order to fulfil their responsibilities) as adequate or better. Still, however, approximately $36 \%$ of the respondents suggested that the capability of their unit was less than adequate or poor. Under $6 \%$ indicated that their unit's capability was excellent.

The responses concerning the availability of resources to operate/maintain the current equipment stock reflected that $38 \%$ of the equipment was less than adequate, $20 \%$ above adequate and $42 \%$ suggested that the available resources are acceptable.

Concerning the ranking of expertise related to utilisation of equipment, $94.5 \%$ of the respondents thought that the available expertise was adequate or better. Thirty two percent ranked the expertise in their units as excellent.

The universities declared, collectively, that they own 884 articles with a replacement value of R376 million. The universities declared just over R123 million was needed to acquire sufficient items of equipment to bring their units to the level of "adequate" 
capability.

However, when they were asked for their "wish list" of the two most needed pieces of equipment in their unit, the total amount came to R175 million (just over 19\% was required for replacement of existing items of equipment).

Eighty eight percent of the respondents needed equipment valued at less than R500 000 per item and 37.5\% equipment valued at less than R80 000 per item.

Approximately $10 \%$ of the respondents mentioned that they had some type of agreement with manufacturers/suppliers. Table 1 shows the countries supplying the most equipment to the universities and the replacement value of such equipment.

\begin{tabular}{|l|c|c|}
\hline Country & Number of equipment & Replacement Value (R million) \\
\hline USA & 264 & 78.8 \\
\hline UK & 76 & 70.2 \\
\hline Germany & 72 & 35.0 \\
\hline Japan & 52 & 29.7 \\
\hline RSA & 35 & 9.9 \\
\hline Netherlands & 24 & 18.5 \\
\hline
\end{tabular}

Table 1: Country of manufacturers of equipment currently available in the SA universities

Only $2.7 \%$, in terms of value, of the equipment have been declared to have been manufactured in South Africa. The USA appears to be the top supplier with the UK and Germany following in the league of suppliers. Table 2 shows the replacement value profile of the equipment.

\begin{tabular}{|c|c|}
\hline Number of equipments & Value Range (R Million) \\
\hline 530 & $<249999$ \\
\hline 156 & 250000 to 499999 \\
\hline 69 & 500000 to 999999 \\
\hline 37 & 1000000 to 1499999 \\
\hline 42 & 1500000 to 2999999 \\
\hline 15 & 3000000 to 99999999 \\
\hline 2 & 100000000 to 500000000 \\
\hline
\end{tabular}

Table 2: Replacement value profile of equipment in the SA universities

Sixty two percent of the equipment belongs to the category below R250 000 per item and approximately another $18 \%$ below the R500 000 mark.

Forty two percent of the number of equipments has been bought during the last five years; approximately $22 \%$ is between $5-10$ years old; and the remaining $36 \%$ are older than 10 years. This profile indicates a relatively old stock of equipment. The 
respective figures for Australia, for example, are $62 \%, 15 \%$ and $18 \%$, while in the USA, 53\%, 24\% and 22\%.

The respondents of the survey have been asked to indicate when the equipment will need to be replaced. Three hundred and five items of equipment valued at R150 million have been identified as having to be replaced in the next five years. Another 284 equipment items valued at R115 million will have to be replaced within this decade.

The average operational time of equipments per week was declared to be 27.7 hours. However, 362 equipments, valued at R99 million, are utilised at less than 10 hours a week and another 153 equipments, valued at R44 million are operational between 10 and 20 hours a week. As utilisation at universities does not follow market principles (owners and users are not charged for the equipment) these usage rates should be seen with concern.

The private sector contributed R26.6 million towards the purchase of equipment at universities (or $7 \%$ of the total replacement value of equipment) of which 33 items of equipment were funded in their totality (R7.6 million). Research councils contributed twice as much as the private sector. They contributed R41.2 million to the universities for the purchase of equipment (11\% of the total replacement value) of which 47 items were wholly funded by the RC's (R14.1 million).

Most of the equipments (86\%) were purchased new and have a replacement value of R281.7 million (74.7\% of the total value). Equipment which was constructed by the universities were valued at R13.6 million and represent approximately 3.5\% of the items of equipment currently available at universities. Equipment which was donated to the universities (including both donated used or new) represent approximately $4.1 \%$ of the items of equipment. Approximately $5.5 \%$ of the items of equipment were bought used.

Of these apparatus, $25 \%$ were reported as being state-of-the-art, representing approximately $45.5 \%$ of the replacement value of all the equipment of the universities. About $75 \%$ of the equipment at universities (or $54.5 \%$ in terms of value) were thought by the respondents to be in good working order.

Referring to the question of adequacy for research or teaching, 37\% of equipment (or approximately $36 \%$ in terms of value) were considered as adequate for research, whilst $68 \%$ (or approximately $75.5 \%$ in terms of value) of the equipment were considered adequate for teaching.

The respondents mentioned that on average $56.4 \%$ of the time the equipment was used for research, $21.5 \%$ for teaching and $6.8 \%$ for testing. Substantial variations existed among institutions. The declared variations were as follows: 


\begin{tabular}{l|c|}
\hline Usage & Maximum and minimum (\% time) \\
\hline Research & 86.8 to 33.3 \\
\hline Teaching & 38.6 to 10 \\
\hline Testing & 30.1 to 0.78 \\
\hline
\end{tabular}

Table 3: Replacement value profile of equipment in the SA universities

The number of researchers/students that utilised the equipment in the last 12 months was as follows:

Type of user

Staff of the unit

Researchers from own institution (not own unit)

Researchers from other institutions

Students
Number

1599

2956

5427

12220

Table 4: Number of users of the equipment in the SA universities

Almost 30\% of the equipment in the universities was declared to be dominated by particular programmes.

The utilisation of equipment per discipline is as follows:

\begin{tabular}{|l|c|c|}
\hline Field & Number of equipments & Percent (\%) \\
\hline Chemical sciences & 89 & 16.5 \\
\hline Biological sciences & 152 & 19.5 \\
\hline Medical \& health sciences & 135 & 17.3 \\
\hline Engineering & 64 & 8.2 \\
\hline Earth and Marine & 58 & 7.4 \\
\hline Physical sciences & 51 & 6.5 \\
\hline Other & 335 & 24.6 \\
\hline Total & $\mathbf{8 8 4}$ & $\mathbf{1 0 0 . 0}$ \\
\hline
\end{tabular}

Table 5: Disciplinary utilisation of equipment in the SA universities

Biological and medical sciences appear to dominate the stock of equipment (36.8\%). It is difficult to assess whether this is the result of these disciplines being more equipment-intensive or whether this is an indication of relevant priorities in the academic environment.

The respondents declared that the equipment was utilised for the following socioeconomic objectives: 
Socio-economic objective

Economic development

Defence

Society

Environment

Advancement of knowledge

TOTAL
Percent (\%)

7.46

0.45

27.94

8.59

48.19

100.00

Table 6: Percent utilisation of equipment in SA universities according to socio-economic objectives

\section{DISCUSSION AND RECOMMENDATIONS}

The investigation of research and training equipment aims to create an informational database and to cast light on associated policy and management issues on a national level.

It has been argued that: modern, well maintained equipment is a prerequisite for high quality research; that instrumentation has a considerable economic impact, as a strong basic competence in generic instrumentation technologies is a key-asset in the effort to capture economic benefits from innovation across the total spectrum of the manufacturing sector; that the technological trajectories of scientific instrument companies differ considerably from other sectors in the economy, indicating that there is great scope for government involvement in encouraging the development of the sector; and that scientific instruments, in the educational field, nurture curiosity, develop skills for inquiry and strengthen practical experience with up-to-date equipment so that students are qualified to meet the needs of industry and commerce.

Despite the overwhelming international evidence of the importance of instrumentation and the inadequacy of the pluralistic system to address failures in the particular infrastructure, both policy makers and individual users of equipment in South Africa do not appear to assign any high priority to the issue.

The institutions visited were overwhelmed with human resource deficiencies and were setting low priority on all other needs including issues of equipment. More importantly, however, the policy makers appear to ignore infrastructural issues. Current legislation, for example, chooses to ignore or deliberately to not address directly infrastructural issues of the nature of equipment. The White Paper on Higher Education mentions equipment only circumstantially and in aggregation with other needs and the National Research Foundation Act does not give the "responsibility" to the Foundation to protect and develop this infrastructural need. It should be mentioned that the NRF is enabled by the Act to support equipment needs, but this does not become an entrenched responsibility in the same way as the disciplinary interests have become.

The importance of the issue becomes more profound when it is taken into account 
that the respondents of the survey have indicated that equipment, valued at R512 million has to be replaced within the next five years, R224 million is required to upgrade the infrastructure so that equipment will not hamper the research and training needs of the institutions and the national research wish-list includes equipment valued at R377 million for expansion and upgrading.

Two issues of policy importance arise from this finding. Firstly the deficiencies in the provision of research equipment cannot be rectified without the injection of additional funds and intelligent future approaches. The term "additional" is used in this instance to not only mean funds outside the S\&T envelope. Different approaches may be required for the different components of the system (e.g. for research councils vis-à-vis academic institutions) although a coordinated effort between, say, DST and the Department of Education may be preferable at least for the next five years (as is expanded in the recommendation section). Such a coordinated effort will also be compatible with the second issue of importance, which is improved management of the provision of equipment.

The size and timing of the need for replacing and upgrading the equipment infrastructure presents a number of opportunities. Promotion/development of local instrumentation manufacturing capabilities; achieving economies of scale through centralised purchasing and bargaining; inducing collaboration and rationalisation are some of the issues that should be considered.

While the above discussed issues are interrelated, the currently used approach of "one size fits all" is inappropriate and unable to solve the country's needs. Local funding programmes have the tendency and the characteristic of having multiple objectives and usually limited resources. The multiplicity of objectives is obviously introduced to satisfy the various constituencies of both funders (including the political authorities) and users and to introduce flexibility to the programme. However, funding programmes are policy instruments and their ability to achieve such policy objectives is considerably impaired when they aim at more than one target. Consequently, although it can be argued that existing programmes, like the Technology and Human Resources for Industry Programme (THRIP) and the Support Programme for Innovation in Industry (SPII), address the needs of the instrumentation industry their impact in the field should expected to be limited. International best practise indicates that more than one instrument (e.g. funding programmes) should be employed for the achievement of any particular objective.

As a comparison, in the USA there are specialised programmes for the support of research equipment. The following are Federal Government programmes within four agencies supporting science and engineering instrumentation in academic institutions:

\section{National Institutes of Health (NIH)}

- Shared Instrumentation Grant Program in Division of Research Resources

- Minority Biomedical Research Support Supplemental Program in Division of Research Resources 
- Shared Instrumentation Grant Program in National Institute of General Medical Sciences

\section{Department of Defence (DOD)}

- University Research Instrumentation Program

\section{Department of Energy (DoE)}

- University Research Instrumentation Program

\section{National Science Foundation (NSF)}

- Chemical Instrumentation Program (within the Division of Chemistry)

- Biological Instrumentation Program (within the Division of Molecular Biosciences and the Division of Physiology, Cellular, and Molecular Biology

- Instrumentation for Materials Research Program (within the Division of Materials Research)

- Engineering Research Equipment Program (within the Division of Materials Research)

- Computer Systems Design Program (within the Division of Computer Research)

- Earth Sciences Instrumentation and Facilities Program (within the Division of Earth Sciences)

- Astronomical Instrumentation and Development Program 9 within the Division of Astronomical Sciences)

- Oceanographic Technology Program (within the Division of Ocean Sciences)

- College Science Instrumentation Program (within the Office of College Science Instrumentation)

The approaches utilised internationally, as have been outlined, are instructive in this instance. In the USA, the NSF has different equipment programmes according to discipline, value of equipment and for development of new equipment. Furthermore, industry is given incentives to donate equipment to universities and government laboratories. According to "Equipment Donation and Discount Scheme" firms donating equipment to identified institutions are allowed to set the full market value against future corporate taxation.

More instructive, however, may be the fact that the majority of funds for equipment abroad comes from a centralised authority and is not left to individual institutions. In the UK, the Universities Grants Council (UGC) provides $46 \%$ of the equipment funding at universities. Similarly, in the USA (despite the decentralised character of the country's science system), Federal Agencies provide more than 55\% of funds for equipment.

At the level of management of equipment the broad picture appears to be far from that of "best practice" internationally. Institutions at best follow normal accounting practices in the depreciation of their equipment, they attempt to keep the equipment budgets separate from other needs and they keep some form of database with their 
equipment. These, however, are isolated cases and do not reflect the South African situation.

A number of participants, though, recognise the need for a more methodical approach and some embryonic efforts are under way to promote some form of cooperation. The regional co-operative initiatives among the various academic institutions and the requirements by the NRF for common or at least supported by other institutions proposals for funding of equipment set the background for some collaboration. This, however, appears at this stage to be restricted in the formulation of funding proposals and at attempts to develop databases of equipment.

We were unable to identify any institution that manages its equipment taking the whole life-cycle into account. More importantly, perhaps is the fact that no guidance is being made available to institutions on the appropriate management of teaching and research equipment on the basis of the whole life-cycle. Current best practice (as suggested by the National Audit Office in the UK) focuses and makes the following recommendations within the different stages of the equipment life-cycle as shown in Fig.2:

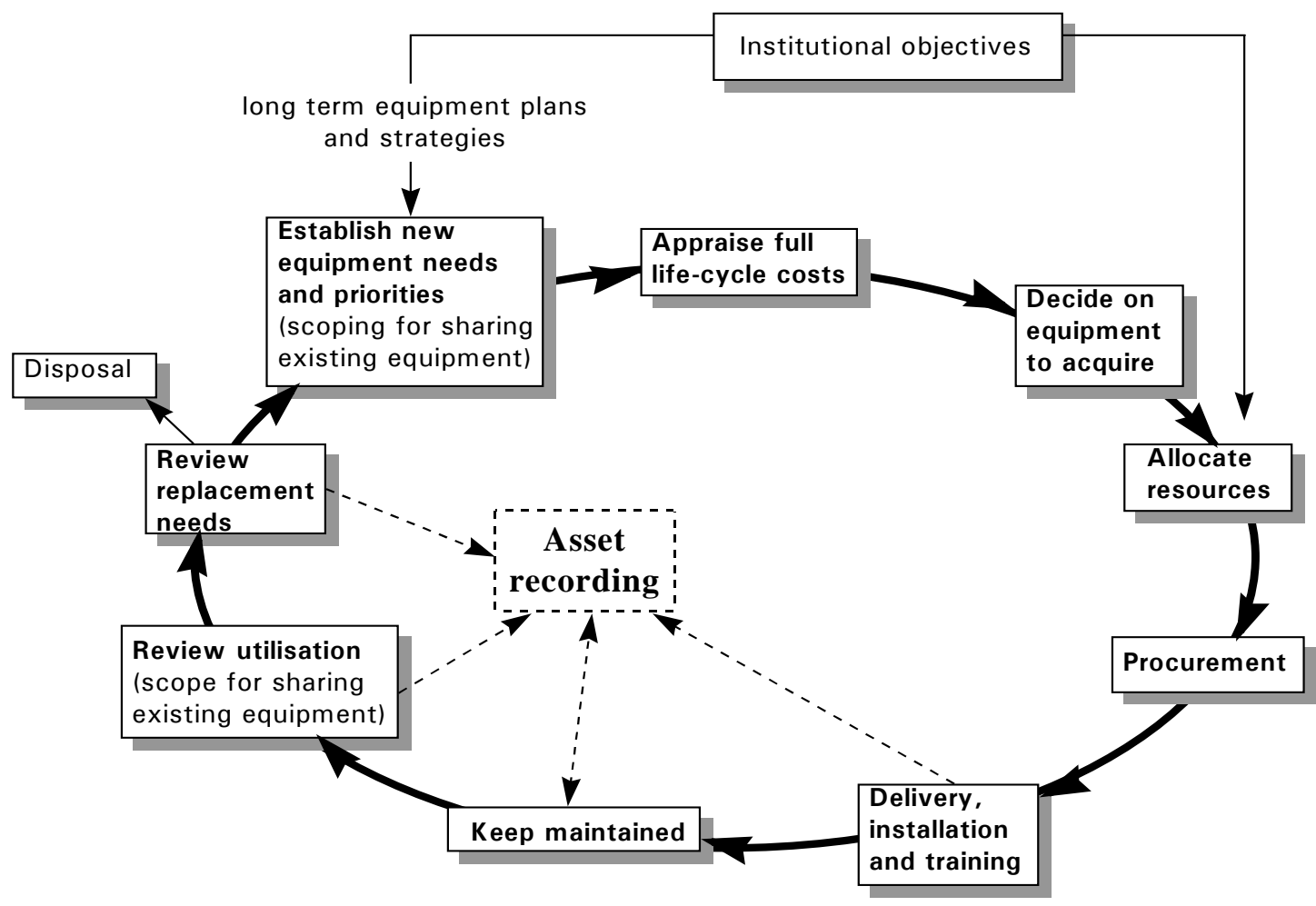

Figure 2: Equipment Life Cycle

\section{Planning}

- there should be a central focus on equipment policies and practice throughout the life-cycle;

- there should be a process for ensuring that the proportion of the institution's budget allocated to equipment is sufficient and is allocated appropriately to meet 
equipment needs. This process would need to be effective in the event of the separate funding stream for equipment from external sources disappearing;

- decisions on the prioritisation of equipment provision should be informed by a longer term perspective of the equipment needed, including the need to replace existing equipment; and

- there should be a methodical approach to deciding on specific items of equipment to fund which takes account of the availability of equipment elsewhere in the institution.

\section{Procurement}

- there should be a proper market search leading to competitive tenders or quotations, and second round of negotiations;

- action should be taken to secure value for money even where there is only one supplier;

- there should be an evaluation of which supplier provides the best value for money in terms of whole life costs, taking account of all relevant downstream costs particularly maintenance, consumables and the provision and cost of spares;

- savings should be sought through combining purchases of common items or negotiating advantageous leasing deals; and

- there should be appropriate application of professional purchasing skills, with the institution's purchasing co-coordinator being involved in all high value expenditure.

\section{Management of equipment through the life cycle}

- formally appraise equipment use, periodically or soon after acquisition, to check that it is meeting its objectives and to identify spare capacity;

- develop mechanisms to encourage the sharing of spare capacity and to ensure that equipment is not purchased by departments without an appraisal of the scope for sharing with other departments;

- cost in-house maintenance and encourage departments to use these costs in deciding on the maintenance strategy for each type of equipment;

- consider whether in-house maintenance can be provided more cost-effectively by means of pooling arrangements;

- more actively consider the merits of extended warranties and institution-wide maintenance arrangements;

- establish standards and procedures for equipment recording, including keeping records up-to-date to ensure completeness and accuracy of records;

- consider the possibility of using internal audit, to ensure that the departmental records meet these standards and procedures;

- press forward with the introduction of standardised systems for purchase and inventory recording;

- use departmental asset records to check that equipment is secure;

- consider arrangements for investment appraisal of, and if necessary, funding for the replacement of equipment with relatively high maintenance costs or where replacement equipment is significantly cheaper to run; and

- in some cases, establish disposal policies. 
On the basis of the above, the following recommendations are offered:

1. DST, within its mandate to co-ordinate the scientific and technological system, should establish an inter-departmental committee on "Critical Scientific and Technological Infrastructures”.

The mandate of the committee should be to investigate and make recommendations concerning policy and programmes affecting "critical scientific and technological infrastructures" such as research and training equipment, scientific and technological telecommunications, and R\&D management.

The Committee should consider among others the viability of introducing:

- the funding of "critical S\&T infrastructures" as a separate line item in the governmental budget [Expenditure defrayed from the National Revenue Account]

- an approach promoting closer collaboration on aspects of critical S\&T infrastructure among organisations reporting to different government departments (e.g. academic institutions, research councils and parastatals).

2. The NRF should institutionalise the support of research and training equipment by establishing an appropriate directorate/division. The division should be funded by Dedicated (earmarked) funds, by top-slicing the budget of the other directorates and by raising funds from local and international donors.

The NRF should establish appropriate 'competitive grants'/funding mechanisms (National Research Foundation, South Africa, 2004 [6]) ${ }^{2}$ promoting :

- the interaction between academia and industry for the development and

- construction of new or improved equipment;

- the maintenance and augmentation of the R\&T equipment infrastructure;

- the development of the necessary infrastructures in institutions that are either lacking or are with deficient infrastructures.

- A programme promoting the development of remote utilisation of equipment should be considered as an urgent priority in view of its possible impact across all other programmes. Different programmes should be established for different objectives.

3. The funding formula of the Department of Education for academic institutions (to be reviewed in 2007) should make R\&T equipment an explicit component of the formula. Furthermore, adequate funds should be earmarked for at least the next six years to facilitate the required replacement and upgrading of R\&T equipment.

4. Benchmarking and adoption of best practice internationally in the management of

\footnotetext{
${ }^{2}$ NRF recently developed a proposal for the Department of Science \& Technology (DST), requesting R100million a year dedicated to support research equipment mainly for higher education institutions.
} 
equipment should become common practice to all relevant institutions in the country. The Committee of Heads of Scientific Councils (CHSC), the South Africa Universities Vice Chancellors Association (SAUVCA) and the NRF may play pivotal roles in investigating best practice internationally and introducing the concepts of management over the life-cycle of the equipment to their institutions. Linking the implementation of the concepts to additional/further funding of equipment may facilitate and speed up the implementation of the approaches.

A number of issues may have been excluded from the scope of this study and may merit further investigation. However, the results of this investigation could be complemented by:

- investigating the availability and state of equipment that could be utilised for research and training but currently utilised for other purposes (e.g. in the business sector);

- investigating the state of the instrumentation industry in the country;

- enlarging the database to include equipment in the major research-performing organisations in the business sector with emphasis on parastatals and businessfunded research laboratories;

- considering as a future option for South Africa, the undertaking of equipment surveys and surveys of facilities as is the practice of the US National Science Foundation (NSF).

- investigating inter-board collaboration

\section{REFERENCES}

[1] Computer Horizons Inc. 1985. “Analysis of the Contribution of Scientific Instrumentation to Highly Cited Research". As quoted in Trends in the Instrument Intensity of Scientific Research at US Colleges and Universities. Proposal to NSF by ABT Associates.

[2] Pavitt K, Robson M, Towsend J. 1989. "Technological Accumulation, Diversification and Organisation in UK Companies”. Management Science, 35(1).

[3] National Science Board (NSB). 1989. Science and Engineering Indicators 1989. National Science Board, Washington DC. USA.

[4] National Audit Office. 1996. "The Management of Teaching and Research Equipment in Scottish Higher Education Institutions" Report by the Comptroller and Auditor General. HMSO, London.

[5] National Science Foundation (NSF). 1996. Research Instrumentation Enabling the Discovery Process. National Science Foundation, Washington DC. USA.

[6] National Research Foundation (NRF). 2004. “A Proposed National Key Research and Technology Infrastructure Strategy”. 